\title{
CONFLICT AND COOPERATION IN PAK-AFGHAN RELATIONS TO RECONCILE THE MISTRUST IN BILATERAL RELATIONS
}

\author{
Huma Qayum* \\ Manzoor Ahmed Naazer* \\ Sadaf Farooque ${ }^{* * *}$
}

\begin{abstract}
Since the emergence of Pakistan the history of Pak-Afghan relations can best be analyzed from conflict to cooperation. Some of the early problems are mainly responsible for conflict and cooperation in both countries relations. After the establishment of democratic setup in both states, different CBMs indicate positive sign in Pak-Afghan diplomatic relationship. The drawdown of US forces has created security concern for Pakistan and Afghanistan that the creation of power vacuum can push the country again into civil war like situation. In such state of security Pakistan's engagement to bring the Taliban to the negotiation table will smooth the way for a broad-based government in Afghanistan. Some of the Afghan domestic political issues also created mistrust i.e., the refugee's problem, cross border militant's infiltrations, drug problem and issue of the Taliban. However, the paper will highlight the measures to keep intact the reconciliation more effective and replace the mistrust by trust. How domestic political issues effect their bilateral relations and why various methods taken in the prescribe time not effective in bilateral relations of the two states.
\end{abstract}

Keywords: Domestic political issues, mistrust, Pak-Afghan relations, cross border militants infiltration, CBMs

\section{Introduction}

Accusations and counter-accusations is the top most agenda of Pakistan and Afghanistan due to rearmost existence of cross-border militant attacks on both sides of the border causing death of innocent civilians on Pak-Afghan border. Due to mistrust, dialogue process has blocked, ambiguity on the part of Afghanistan started balm game on neighbors especially on Pakistan derail the dialogue process. Pakistan on several occasions rejected the accusation to sponsor Taliban but show willingness for the stability and prosperity of Afghanistan ${ }^{1}$.

\footnotetext{
${ }^{*}$ Huma Qayum, Ph.D. Political science scholar at department of political science international Islamic University Islamabad, IIUI

*** Manzoor Ahmed Naazer, Assistant Professor, Department of Politics and IR International Islamic University Islamabad

${ }^{* * *}$ Sadaf Farooque, Assistant Professor, Department of Politics and IR International Islamic University Islamabad

${ }^{1}$ TTP Sanctuaries. The News International. (November 18, 2017). P.8 Retrieve on

https://epaper.dawn.com/DetailNews.php?StoryText=18_11_2017_008_002
} 
The tumultuous relationship between Pakistan and Afghanistan (Pak-Afghan Relations) has mostly remained far from being normal. Besides common ethnic, linguistic, cultural and religious ties, these two strategically important neighboring Muslim countries share a very long common border which divides the ethnic tribes of Pashtuns in two geographic units. The tribes on both sides have strong traditional and social ties but ironically, the administration on both sides has always been at loggerhead with each other. No doubt, this state of antagonism was due to some vested interests and mainly due to misperceptions on both sides. It is more than obvious that since independence of Pakistan on 14 August 1947, the strained Pak-Afghan relations moved from bad to worse. When the then Afghan government obstructed Pakistan's entry into the United Nations (UN) in September 1947, raising the issue of Pakhtunistan and altogether the negate to the international Pak-Afghan border-Durand line. It was only that brief period of 5 years that blame-game vanished. Since the ouster of the Taliban regime relations suffered from distrust $^{2}$, Pakistan's engagement in efforts, to find a peaceful end to the conflict in Afghanistan added strength to the Peace Process ${ }^{3}$. Peace and stability in Afghanistan is one of the objectives of Pakistan's foreign policy ${ }^{4}$. Moreover, it is also an essential factor for peace and stability in Pakistan and a logical end to the violence. The Taliban are followers of an ideology. Due to its harsh laws, it is necessary to be debates with them to find a viable path to restore normalcy to the war-torn country, as fighting is not the solution to restore Peace in Afghanistan. ${ }^{5}$

\section{Bone Agreement and Pakistan's Role}

At the end of Operation Enduring Freedom and to demolish the Taliban government in 2001, to re-create the state of Afghanistan, a conference of Afghan leaders was held in Bonn a city of Germany at Petersburg hotel. The Taliban were not included in talks, eighteen states representative took part as an observer states. ${ }^{6}$ It recognized a timetable for establishing peace and security, reconstructing the country, re-establishment of some key institutions, human rights protection and addressing military demobilization and integration. $^{7}$

As for as the role of Pakistan in Afghan Bonn Conference, Pakistan welcomed the Bonn agreement among the Afghan members and offered facilitation to the UN General Secretary Kofi Anan and his special representative Lakhdar Brahimi. Pakistan foreign

${ }^{2}$ Chandrasekaran, R. 'Little America': Infighting on Obama Team Squandered Chances for Peace in Afghanistan. Washington Post, June 24. 2012. Retrieved on July 8, 2012, from The Washington Post :http://articles.washingtonpost.com/2012-06 24/world/35462009_1_richard-holbrooke-afghanistan-warstrategy-obama-white-house/4

${ }^{3}$ Yousaf, Khattak. Reconciliation: Afghan Peace Delegates Kicks off Key. Express Tribune, November 13, 2012.

${ }^{4}$ Dr. Maqsudul Hasan Nuri, Acting President IPRI. (2012, June 29). Published in the Frontier Post (Peshawar). Retrieved from http://ipripak.org/articles/latest/APTTA\%20I.pdf

${ }^{5}$ Fergusson, J. Taliban: The True Story of The World's Most Feared Guerrilla Fighters. (London: Bantam Press, 2010). P.2

${ }^{6}$ Filing the Power Vacuum: The Bonn Conference. (2001, December 27). Frontline. Retrieved from https://www.pbs.org/wgbh/pages/frontline/shows/campaign/withus/cbonn.html

${ }^{7}$ Afghanistan's Bonn Agreement One Year Later: A Catalog of Missed Opportunities. (2002, December 5). Huma Rights Watch. Retrieved from https://www.hrw.org/news/2002/12/05/afghanistans-bonn-agreement-oneyear-later 
Ministry spokesman Aziz Ahmad khan in a statement said, that "the tidings from Bonn as an encouraging moment for an end to the efforts of Afghan people". He further added, "Pakistan too has borne heavy economic social costs because of the Afghan conflict. The provision of asylum to over three million refugees has resulted in consequential environmental damage, proliferation of weapons, narcotics trafficking, smuggling and terrorist crimes" ${ }^{\prime}$. Pakistan practically not participated due to Salala Accident in which US forces targeted two Pakistani check posts adjacent to Pak-Afghan border (Shaukat, 2016). In this accident 24 soldiers of Pakistan army along with one major and a captain killed. Salala attacks are more offensive accident on Pakistan's military bases launched by US forces. In reaction Pakistan thwart NATO supply routes, emptying of Shamsi airbase from NATO forces in Baluchistan, Pakistan's call for apology, stubbornness of US officials, elimination of Drone attacks in Pakistan territory, boycott of Bonn conference on $5^{\text {th }}$ December 2001 on Afghan political settlement, denial of Pakistan to take part in Afghan exit strategy, settlement of border issue with Afghanistan, hazard to US to block Pakistan's assistance and proposed decision of the Afghan war are all the main events occurred with Salala accident ${ }^{9}$.

\section{Abbottabad Operation and Death of Osama Bin Laden}

Operation Neptune Spear, the code name of CIA-led Joint Operation with Special Operations Command also known as JSOC a special unit involved in operation. Osama Bin Laden, leader and founder of the first Islamists group Al-Qaeda was shot dead in Abbottabad (Pakistan) along with 4 other peoples on May 2, 2011 by US Navel Special Welfare Group, together Bin Laden's body, a hoard of computer data and other devices. ${ }^{10}$ The attack was launched from Afghanistan, 120 miles (129 km) inside Pakistan, adjacent to grounds of Pakistan's military academy Kakul, the raid were supported by $90 \%$ of US public and welcomed by UN, NATO and European Union countries ${ }^{11}$ These are some of the events which destabilized both countries relations.

\section{Confidence Building Measures (CBMs) of The Two States}

President Karzai shown an interim head of state under 30 members interim government on December 22, 2001. While, the first ever presidential elections in Afghan history held on October 9, 2004 in which Karzai elected as president for five years term. Afghan second presidential election of August 20, 2009 provided a welcome shift in its policies towards Pakistan as compared to Karzai first term in office in the consequences of first presidential elections of October 9, 2004, which engulfs Pakistan under chaos and blame game and Pak-Afghan relationship was hitting on lowest level. Hamid Karzai, after his reelection, avail a further chance to boost the efforts towards cordiality in the relations;

\footnotetext{
${ }^{8}$ Hussein, Shahid. Pakistan welcomes Bonn agreement. Gulf News General. (2001, December 1). Retrieved from https://gulfnews.com/news/uae/general/pakistan-welcomes-bonn-agreement-1.431752

${ }^{9}$ Shaukat, Reema. Remembering Salala. The Nation. (2016, November 26). Retrieved from https://nation.com.pk/26-Nov-2016/remembering-salala

${ }^{10}$ Drogin, Bob \& Dilanian, Ken. Obama’s Gamble. Los Angeles Times. (2011, May 3). Retrieved from http://articles.latimes.com/2011/may/03/world/la-fg-bin-laden-raid-20110503

${ }^{11}$ Brown, Adrian. OsamaBinLaden's death:How ithappened. BBCNews. (2012, September 10). Retrieved from http:/www.bbc.com/news/world-south-asia-13257330
} 
Karzai was emboldened to stand up to the US policies once he found Pakistan on his side. ${ }^{12}$ During an interview with Pakistan largest satellite network Geo TV, Karzai remarked that "if there is war between Pakistan and US, we will stand by Pakistan. He puts his hand on his heart and described Pakistan as a 'brother' country and Afghanistan will never betray their brother". ${ }^{13}$ Most notably, he has not only acknowledged the role of Pakistan in fighting against militancy but had stopped issuing hostile statements and accusations against Pakistan for each nuisance which his country faced. The Kabul regime has been looking more towards Pakistan's assistance than that of the US for ensuring stability in the country. In the wake of the planned US drawdown, Karzai understood he would be left alone and needed to secure himself with Pakistan's assistance. There was a realization within the Afghan regime that they were bound to accommodate Pakistan's wishes in the future policy set-up. Particularly, the situation emerged after the Pak-US strategic dialogue where it became apparent that the US also needed Pakistan backing in Afghanistan. ${ }^{14}$

To give imputes in two countries bilateral relations, Prime Minister Gillian's visit to Afghanistan on April 16, 2011 the two countries state representatives reiterated to set-up a two-tier elevated level joint commission to carry forward the reconciliation process after the withdrawal of United States-led International Security Assistance Forces (ISAF) troops. It was decided mutually to resolve the issue of militancy and find a negotiated settlement of insurgency through mutual consultation. President Karzai said, "The joint peace commission which used to be at the level of Foreign Ministers has been upgraded by Pakistan to the highest governmental level". Prime Minister Gillani along with Chief of Army Staff (COAS) General Ashfaq Pervez Kiyani and Director General InterServices Intelligence (ISI) Lt-General Ahmad Shuja Pasha also held extensive talks with the HPC Chairman Burhanuddin Rabbani to boost the efforts of the Peace Process. It was for the first time that both military and political leadership held discussion under oneroof. ${ }^{15}$ To endorse CBMs, Pakistan released about 7 to 9 Taliban on November 15, 2012, to facilitate talks. ${ }^{16}$

Salahuddin Rabbani, Chairman of HPC came to Pakistan on November 12, 2012, an encouraging move in both countries relations. ${ }^{17}$ Inclusion of Pakistan in the HPC coregroup format was a great achievement from Afghan side, Pakistan was also optimistic to

\footnotetext{
${ }^{12}$ Safi, Saleem. End-Game in Afghanistan. (2011, April 30). Retrieved from http://www.pkarticleshub.com/2011/04/30/end-game-in-afghanistan/

${ }^{13}$ The Guardian. (2011, October 23). Retrieved from http://www.guardian.co.uk/world/2011/oct/23/hamidkarzai-us-pakistan-afghanistan

${ }^{14}$ US say Pakistan's role indispensable in Afghanistan. (2010, June 4). Dawn News. Retrieved from http://www.dawn.com/wps/wcm/connect/dawn Content-Library/dawn/the-newspaper/front l page/us-sayspakistan-indispensable-for-success-in-afghanistan-460

${ }^{15}$ Yousaf, K. Reconciliation: Afghan Peace Delegates Kicks off Key. Express Tribune, November 13, 2012.

${ }^{16}$ Kakar, Javed Hamim. Pakistan, Afghanistan ink MoU on rail link. (2010, July 7). Retrieved from http://www.pajhwok.com/en/2010/07/07/pakistan-afghanistan- ink- mou-rail-links

${ }^{17}$ Grare, Frederic. Pakistan-Afghanistan Relations in the Post 9/11 Era: Carnegie Endowment for

International Peace. 2006
} 
bring major policy shift to improve its strategic ties. At the time, Pakistan was on 'tenterhooks' to play its role in Afghanistan. ${ }^{18}$

\section{Domestic Political Issues and Mutual Co-operation}

Cross border military infiltration was a great security concern for Pakistan. Due to unusual occurrence of shelling and firing on both sides the process of reconciliation derailed and both states started to blame each. To further augment this process, a Tripartite Commission was setup in 2003. In fact, cross border incursions were of great concern for both sides especially after the expected US-led NATO intervention in Afghanistan in October 2001. The newly formed Tripartite Commission comprised of senior military and diplomatic officials from Afghanistan, the US and Pakistan side. It was an effort to facilitate communication and information sharing among the three stakeholders to avoid border incidents in future. ${ }^{19}$ In July 2010, Prime Minister Gillani paid a special visit to Afghanistan to boost the efforts to stop cross border incursions similarly Karzai was determined to resolve this issue through Border Mechanism Commission during his visit to Pakistan in June 2011. ${ }^{20}$ In June 2011, in a news conference, President Karzai expressed that he wanted to see a non-violent and quick political solution to the problem. On July 7, 2011, Prime Minister of Pakistan in response to Kabul statement, made a phone call to President Karzai and assured that Pakistan army was exercising 'utmost restraint' against militants and cross border incursion from Afghanistan. Prime Minister Gillani said, "the situation 'needs to be defused quickly." The two leaders also discuss cross-border violations and terrorist's attacks from the Afghan side. ${ }^{21}$

This border violation posed a threat to the Peace Process. On one occasion the then Interior Minister of Pakistan Aftab Ahmad Khan Sherpao that the border should be fenced to stop foreign infiltration. ${ }^{22}$ This idea set in with the passage of time and border fencing started from Pakistan's side under Pak-army supervision with the support of Pakistan's tribal region. fencing of Pak-Afghan border started in June 2016. It is $2300 \mathrm{~km}$ international border declared by Afghans a disputed border, on $45 \mathrm{~km}$ area fencing work done. This project depends upon three phases first border fencing on all areas connected to Pak-Afghan borders, second component is border forts and third is border management system control on informal cross bordering. Paktika and Khost villages can clearly seeing from Pakistan border side. Nearly 750 forts will be constructed on 1 to $3 \mathrm{~km}$ in which 92

\footnotetext{
${ }^{18}$ Saleem, M. \& Ozair, S \& S.Goraya N. Post-2014 Afghanistan. South Asian Studies, (2013, January-June). 28(1), 67-84.

${ }^{19}$ Siddiqi, S. Pakistan-Afghanistan Relations: History and Geopolitics in a Regional and Global Context. Waltz and Duncan Foundation Report. 2009.

${ }^{20}$ Pakistan, Afghanistan to Coordinate Amid Cross-Border Confusion. Express Tribune, July 17, 2011. Retrieved on September 30, 2011, from http://paktribune.com/news/Afghanistan-Pakistan-to-coordinate-amidcross-border-confusion-241278.html

${ }^{21}$ Ibid.

${ }^{22}$ Grare, Frederic. Pakistan-Afghanistan Relations in the Post 9/11 Era: Carnegie Endowment for International Peace. 2006
} 
forts are completed. ${ }^{23}$ This will not only regulate the movement of people and goods but will also check militant's infiltration from across the border. ${ }^{24}$

\section{Refugees and Drugs Problems}

In Pakistan currently 3 million Afghans living as immigrants in which 1.6 million are registered and rest are unregistered Afghans. Migration of the Afghans are the great disaster, particularly for Pakistan and Iran. Law and order situation, unemployment, prolonged war and insecurity are the main reasons which compelled the Afghans for migration. ${ }^{25}$ As indicated by sources 3.7 million Afghan refugees came to Pakistan. Its accommodation was a complicated task for the government of Pakistan and great burden on its economy. In Geneva convention to elevate relief requirements, Pakistan asked for the United Nations Higher Commissioner for Refugees (UNHCR). An emergency aid of $\$ 10.3$ was released for one-year assistant program, to cover 185,000 thousand refugees till September 1980. The Soviet direct assault increased the growth of refugee's population in Pakistan, almost 300,000. Such a substantial number migrates, activated many relief organization like, Save the Children fund, World Health Organization (WHO), The League of Red Cross Societies, the Pakistan Red Crescent Society, Church International Service, UNICEF, WFP, FAO, Australian Relief Care, UNHCR and other international relief agencies risen to nearly $\$ 100$ million. Apart from the United Nations, twenty-eight international and voluntary agencies are involved in Afghans rehabilitations process. $^{26}$

Several security and terrorist accidents occurred in Pakistan due to the presence of Afghan migrants. ${ }^{27}$ The Pakistani land utilized by the insurgents for their activities, such as arranging operations, recruiting and training fighters, financing operations and providing logistics support to the insurgents. ${ }^{28}$ Following are the main factors which forced the Afghans to leave the country;

- Insecurity and War: From last 16 years Afghanistan is under war, civilian causalities and the country unstable situation compelled the masses for migration.

- Unemployment: Due to lack of employment for millions of youth in Afghanistan. Most of the youth for job purposes rush to Europe and industrial states.

\footnotetext{
${ }^{23}$ Qadir Khan, Ghulam. Fencing the Tribal Areas. Daily Dawn. (2017, December 4). Retrieved from https://epaper.dawn.com/DetailNews.php?StoryText=04_12_2017_008_004

${ }^{24}$ Ibid.

${ }^{25}$ Center for Strategic and Regional Studies. The Migration Crisis and the Situation of Afghan Migrant in the World. Weekly Analysis. Issue number, 150. Kabul. (August 23, 2015). Retrieved From http://csrskabul.com/en/blog/the-migration-crisis-and-the-situation-of-afghan-migrants-in-the-world/

${ }^{26}$ R. Girardet, Edward. Afghanistan: The Soviet War. Croom Helm: London UK. 1985. P, 203.

${ }^{27}$ Larsdotter, Kersti. Regional Support for Afghan Insurgents: Challenges for Counterinsurgency Theory and Doctrine. Journal of Strategic Studies, 37(1), 135-162. (2014)

${ }^{28}$ ibid
} 
- Economic Problem: As a poor and lack of industrial state most of its youth are in search of migration to western and developed countries.

Drug production and drug trafficking has great effects as well as causes for political instability. They flourish under weak sates and withstand that weakness by financing insurgency and warlords. It also intimidating the official of enforcement agencies and security forces. Drug malfunctions are connected to deficiencies in security and governance. Many counter-narcotic efforts were taken for the political and administrative stability, but not successful in case of Afghanistan. ${ }^{29}$ Pakistan also directly effected by the opium production of Afghanistan, Pakistani Tribal Areas, Khyber Pakhtunkhwa and Baluchistan. Malakand division, Swabi and Gadon Amazai a mountainous region of KP was well-known for poppy cultivation. Gadon became the hub of Pakistan illicit opium production to the world narcotic market. The CIA covert operation in Afghanistan against the Soviet forces turned the Pak-Afghan borderland into the world top illicit opium production areas which produced almost $60 \%$ heroin demand of the USA. Due to drug money corruption in governmental sectors are on the top. According to the 2004 Transparency International Report, law enforcement members and judiciary personal established working partnership with the drug dealers, which caused the general domestic feasibility of opium cultivation. ${ }^{30}$ These two unresolved problems have also the cause of hostile terms in the two states.

\section{Military CBMs}

On military side of the cooperation, Pak-Army Chief Gen. Kayani met Afghan President Karzai along with other officials, including ISAF Commander General. David Howell Petraeus and Afghan National Army Chief of General Staff Gen. Sher Muhammad Karimi, on the sidelines of the $31^{\text {st }}$ Tripartite Commission meeting in Kabul, the two leaders discussed the new counter-terrorism strategy for the region. ${ }^{31}$

\section{Transit-Trade Relations of the Two States}

Major policy shift in both countries relations came in the farm of signing AfghanPakistan Transit Trade Agreement APTTA. From May 2009 to July 2010 seven meetings were held between the two countries' concerned departments keeping in view the previous short comings and inputs of 1965 ATTA both the sides agreed to resolve each other's concerns in a positive manner. To resolve many anxieties at last this historical document was signed on October 28, 2010 in Islamabad the capital of Pakistan and operationalized on June 21, 2011 due to replacement of bank guarantees with insurance

${ }^{29}$ P. Caulkins, Jonathan, A.R. Kleiman, Mark. D. Kulick, Jonathan. Drug production and Trafficking, Counter Drug Policies, and Security and Governance in Afghanistan. Center on International Cooperation. New York University. (2010).

${ }^{30}$ Khan, Waseem \& Ahmad, Manzoor. History of Opium Cultivation in Pakistan: Socio Economic Significance and Politics of Opium Eradiation. Science Int. Lahore, Vol, 28 (2). 2016.

${ }^{31}$ Kiyani Meets Karzai, Discussion Anti-Terrorism Strategy. Daily Times, September 8, 2010. Retrieved on October 6, 2011, from The Daily Times: http://www.dailytimes.com.pk/default.asp?

Page=2010108\10\story_10-8-2010_pg7 
guarantees for goods carrying vehicles. ${ }^{32}$ Pakistan side led by Minister of Finance and Economic Affairs Dr. Abdul Hafeez Sheikh, and Afghanistan side led by Afghan Finance Minister Hazrat Omer Zakhilwal. The 'two countries signed a 'Note for the Record' on July 18, 2010 in which Pakistan agreed to allow Afghan trucks to ply between Afghanistan and Karachi and Wagha carrying Afghan transit goods. ${ }^{33}$ Both countries agreed to start bilateral trade by finalizing details of the installation of biometric system and tracking devices on transport units; and agreed to lay a railway track between Pakistan and Afghanistan. To link Quetta (Baluchistan) to Southern Kandahar and Peshawar to Jalalabad both countries agreed on it. Ghulam Ahmad Bilour Pakistan's Ministers of Railways said to the press conference that the expenditure of project will be divided between the two countries. ${ }^{34}$

Final round of trade agreement between the two countries was signed on October 28, 2010 at Kabul superseded ATTA of 1965, the signing was witnessed by the US Special Representative for Afghanistan and Pakistan, Richard Holbrooke for foster trade relations. ${ }^{35}$ Such agreement also provided Afghanistan strategic access to Gawadar and port Qasim to give opportunity to Afghan traders and farmers to expand their trade to the Central Asian countries. This will also enable Pakistan and other regional countries to use Afghanistan as a Transit corridor to trade with Central Asian countries. APTTA put in practice on June $12,2011 .^{36}$

New efforts to resolve the trust deficit, on November 21, 2012, Pakistan and Afghanistan signed the 36tripartite border commissions in Kabul in the presence of Chief of Army Staff (COAS) General Ashfaq Parvez Kiyani, Afghan Chief of General Staff (COGS) General Karimi and ISAF Commander Lieutenant General Carter known as the Tripartite Border Coordination Mechanism, border security management were also point of the agenda. ${ }^{37}$ Following an official invitation by President Asif Ali Zardari, Afghan President Hamid Karzai paid a two-day visit to Pakistan along with high delegation on February 2012. During a meeting with his counterpart Zardari and PM Gillani; Karzai, officially opened the joint peace commission for this purpose. ${ }^{38}$

President Zardari along with his Afghan and Turkish counterpart attended the $7^{\text {th }}$ Trilateral Summit in Cankaya Presidential Palace in Turkey on December 13, 2012. On this occasion President Zardari said that Pakistan would always support the efforts, which were in the best interest of Afghanistan as well as Pakistan for the security and prosperity

\footnotetext{
${ }^{32}$ Khan, Adil. Audit of Trade Facilitation Measures for Enhancing Pakistan Light Engineering and Made up Articles Exports to ECO Countries. Draft Report. (November 2011).

${ }^{33}$ Ibid (November 2011).

${ }^{34}$ Kakar, Javed Hamim. Pakistan, Afghanistan ink MoU on rail link. (2010, July 7). Retrieved from http://www.pajhwok.com/en/2010/07/07/pakistan-afghanistan- ink- mou-rail-links

${ }^{35}$ Kiani, Khaleeq. Pakistan-Afghan accord on transit trade. Dawn News. (2010, July 19). Retrieved from http://www.dawn.com/wps/wcm/connect/dawn-content-library/ dawn/news/world/44-pak-afghan-reachconsensus-over-transit-trade-fa-05

${ }^{36}$ Dr. Maqsudul Hasan Nuri, Acting President IPRI. Published in the Frontier Post (Peshawar). (2012, June 29). Retrieved from http://ipripak.org/articles/latest/APTTA\%20I.pdf

${ }^{37}$ Securing Border. News international, November 22, 2012, p. 7.

${ }^{38}$ Retrieved from http://www.afghanistanembassy.no/article/70986/H-E-President-Hamid-Karzai-visitsPakistan-
} 
in the region. A delegation from Afghan side visited Pakistan on January 27, 2013 to improve bilateral relations during the meeting "Tripartite Border Standing Operating Procedures" were also discussed. It was about sharing border mechanisms and cooperation for the improvement of security and defense to get related help from Pakistani authorities. $^{39}$ US is also anxious about peaceful withdrawal from Afghanistan. Negotiating a deal with the Taliban was the only viable strategy considered by the US to put an end to the war. This option was also in the best interests of NATO troops. The four-tier leadership of the three countries, Afghanistan, United Kingdom (UK), and Pakistan, met on February 3-4, 2013 in London to held discussion with the Taliban. The leaders of both countries agreed upon arrangements to strengthen coordination by taking more $\mathrm{CBMs}{ }^{40}$

\section{New Governmental Setup in Pakistan}

May 11, 2013, General Elections brought a new set-up in Pakistan. The Afghan Government expressed the prospect of co-operation from Sharif's Government in Pakistan. Afghanistan was cautiously optimistic about the role of Pakistan Muslim League (Nawaz) government to play its role in the elusive peace and reconciliation process. ${ }^{41}$ President Karzai, on June 6, 2013 made a phone call to the newly elected Prime Minister of Pakistan Nawaz Sharif and commended him on his assumption of the office of the Prime Minister and invited him to visit Kabul with a hope that both the countries would continue to work for further improvement in the bilateral relations. Nawaz Sharif after assuming office as Prime Minister also assured to establish better relations with Afghanistan. The new Government in Pakistan was considering the issue more hopefully. The PML (N) was more sympathetic towards Pakistani and Afghani Taliban and could assist in peace efforts in Afghanistan. Pakistan's commitment was to support all initiatives and to contact regional stakeholders in Afghanistan aimed at promoting peace and stability in Afghanistan. Premier Sharif reiterated Pakistan's commitment during the visit of British Foreign Secretary William Hague to Pakistan on July $18,2013 .^{42}$ On July 21, 2013, a Senior Pakistani diplomat, and Special Adviser on national security and foreign affairs, Sartaj Aziz paid a visit to Kabul for talks with President Karzai and conveyed a goodwill message from the new Government to start a new era of good relations. ${ }^{43}$

\section{Nawaz Sharif Visit to Afghanistan}

On November 30, 2013 Prime Minister Nawaz Sharif during his first visit to Afghanistan after talking oath for the third time, expresses his views, "it is an imperative to reverse the destructive cycle of conflict. Pakistan will continue to extend all possible facilitation for the Afghan Peace Process" In response to these views President Karzai said, "there is no

\footnotetext{
${ }^{39}$ News international. January 29, 2013. p. 1.

${ }^{40}$ Brunnstrom, D. US Seeks to Ease Afghan-Pakistan Tension in Brussels Talks. Retrieved on April 26, 2013, from http://www.reuters.com/article/2013/04/24/us-afghanistan-talks-idUSBRE93NOMU20130424

${ }^{41}$ Islamabad's Future Role in Afghanistan. May 13, 2013. Afghanistan Express. Retrieved on April 23, 2013, from:http://theafghanistanexpress.com/islamabads-future-role-in-afghanistan/

${ }^{42}$ Pakistan Committed to Afghan Peace. Pakistan Observer, July 19, 2013 p. 1.

${ }^{43}$ Ibid.
} 
doubt that cooperation and relations with Afghanistan have expanded since Nawaz Sharif has taken office. ${ }^{44}$ President Karzai also remarked "terrorism and extremism are threats for both countries, we discussed the shelters and havens which are present in the region and we talked about how to put a stop to them." Prime Minister Sharif expressed, that "in our view, the key to sustainable peace in Afghanistan - 2014 and beyond - is an inclusive political settlement."

\section{Ashraf Ghazni visit to Pakistan}

Soon after taking oath as a President of Afghanistan on 29 September 2014, Ashraf Ghazni visit to Pakistan General Head Quarter GHQ was a paradigm shift from conflict to cooperation. His gesture carries two clear messages firstly he understood the Pakistan military paramountcy oversight of its country foreign policy with Afghanistan and second, he stressed on Pakistan military to deliver the Quetta Shura that last reconciliation step with the Taliban could be achieved. At the end a MoU was signed with Pakistan ISI and the National Directorate of Security (NDS) respectively with the aim to eradicate the remnants of terrorist safe heaven. ${ }^{45}$ On October 2, 2017 COAS General Qamar Javed Bajwa on the invitation of President Ghani visited Afghanistan, one on one meting held among the two leaders in Presidential palace. Ghani said on this occasion, both are friendly nations and joint working can move ahead peace and reconciliation of the two states. President Ghani accepted Pakistan's invitation. ${ }^{46}$

In March 2018, US vice President Mike Pence and Shahid Khaqan Abbasi Prime Minister of Pakistan held a meeting in Pakistan. In which Pakistan has clarified that it is ready to cooperate in the Afghan reconciliation process according to its national security policy. For this purpose, cooperation of the Afghan government and the US will have to make framework for dialogue strategy. This backdoor diplomacy started after the proclamation of the Afghan government initiative to talks with the Taliban for the rebuilding of reconciliation process. ${ }^{47}$

\section{Prime Minister Shahid Khaqan Abbasi visited Kabul}

Pakistan's Prime Minister Khaqan Abbasi paid a one-day trip to Kabul on April 6, 2018. Several bilateral issues were discussed on this occasion, the visit was considered forthright and candid on both sides. Discussions were held on reduction of violence,

${ }^{44}$ Ali Syed, B. "Karzai Offered Help or Talks with Taliban”. Daily, Dawn, August 27, 2013. p. 1.

${ }^{45}$ Zulfiqar, Saman. Pakistan -Afghanistan Relations. IPRI Review. (October 7, 2015). Retrieved from http://www.ipripak.org/pakistan-afghanistan-relations/

${ }^{46}$ Afghan President Ashraf Ghani to visit Pakistan in 'near future'. The Express Tribune. (October 7, 2017).

Retrieved from https://tribune.com.pk/story/1525341/afghan-president-ashraf-ghani-visit-pakistan-near-future/

${ }^{47}$ Khan, Amir. Pakistan, US agree to enhance coordination for Afghan peace process. The Express Tribune. (March 23, 2018). Retrieved from https://tribune.com.pk/story/1667276/1-pakistan-us-agree-enhance-

coordination-afghan-peace-process/ 
peace and reconciliation, repatriation of Joint Economic Development and return of Afghan refugees. ${ }^{48}$

\section{Conclusion}

Some of the Afghanistan domestic political issues are mainly responsible in tense ties of the relations. In the real sense the above issues are the key matters which fragmented the reconciliation process and bridge the mistrust. However, the growing relations between Pakistan and Afghanistan in the form of different CBMs and Peace Process will smooth the way for future development in the relations. Pakistan and Afghanistan cooperation will end the growing enmity that it has been facing since independence. No doubt, the Peace Process has opened the door of new development in the relations which will bring the era of stability, progress and economic development for both the countries. Since the commencement of new democratic set-up in Pakistan in May 2008 as well as in Afghanistan, it raised hopes for wide ranging discussions which held between the two countries. Karzai stance towards Pakistan was also positive after elected president for the second term as compared with his first term which engulf Pakistan under blame game and militant's infiltration. Pakistan new governmental setup was also optimistic and has taken many measures for peace in the region and extended hands of cooperation with Afghanistan. Military established is also on same page, took several steps to bridge the trust deficit. It is hope that in new future President Ashraf Ghani will cooperate in bilateral relations to move the relations from conflict to cooperation.

${ }^{48}$ Islamabad, Kabul to Reframe Terms of Engagement. Daily Dawn. (April 7, 2018). Retrieved from https://epaper.dawn.com/?page=07_04_2018_001 